\title{
THE HYPERTROPHY OF \\ Polish RemembranCe Policy AFTER 2015: TRENDS AND OUTCOMES
}

\section{Tomasz Stryjek*}

\begin{abstract}
Polish authorities have placed so much importance on remembrance policy since the end of 2015 that it has led to the hypertrophy of the phenomenon. From the 1990s, Poland has been at the forefront of shaping the infrastructure of this form of politics in Europe. Admittedly, even before 2015, national remembrance policy referred mainly to martyrologic and heroic experiences from the period 1939-1956, but it was the victory of Law and Justice in the elections in 2015 and the creation of a oneparty government that resulted in the repeated official declarations of the necessity to defend national "dignity". This has been accompanied by wiping from national memory past crimes committed by Poles, particularly against Jews.
\end{abstract}

Keywords: remembrance policy, politics of memory, identity policy, historiography, Institute of $\mathrm{Na}$ tional Remembrance, museums, public holidays and memorial days, Central and Eastern Europe

Creating the English-language version of the journal "Zoon Politikon" is financed under contract No. 724/P-DUN/2018 from the funds allocated by the Minister of Science and Higher Education for dissemination of science.

\footnotetext{
*Tomasz Stryjek, Ph.D., Institute of Political Studies Polish Academy of Sciences, Collegium Civitas, Warsaw, Poland, mail: tstryjek@wp.pl |ORCID: https://orcid.org/0000-0002-9137-7537
} 
Introduction

Law and J ustice (PiS), ruling in Poland since November 2015, has discredited the state's remembrance policy. Three years on from the elections of 2015, it is unfathomable that, would should Law and J ustice be removed from power by the centrist and leftist forces, the new rulers would consider the shaping of unified collective memory as the duty of the state. The Civic Platform (PO) leader, Grzegorz Schetyna, already in October 2016 announced future dissolution of the Institute of National Remembrance (IPN). This is a breakthrough in the history of the political life of the Third Polish Republic, which has its origins in the democratic opposition of the pre-1989 period. In 2018, attempts on the part of Law and J ustice and by Kukiz'15, a political movement with representation in the parliament, to achieve unambiguity in the assessment of the past led to some historical disputes having to be settled in courtrooms, and it also dragged state authorities into conflict with important foreign partners.

Although it should not be linked to the origin of all the clashes, since coming to power in 2015, the right wing has definitely inflamed them. The ruling party refused to consider that politics is the art of achieving the possible. If the subject of one's policy is not negotiable and is not accompanied by an offer of benefits for the counterpart, one can succeed in political actions only being far superior to the other party. When there is no such advantage, the policy eventually becomes ineffective and ridiculous, amusing even. In fact, the conduct of Polish state authorities towards foreign partners since 2015, must be viewed less in terms of meting out justice to the participants of the events of 19391989, and more in connection to the "dignity" of the leaders of the ruling party. As representatives of Poland in the international arena, they were not allegedly shown respect their country's strength and significance merited. However, the demand for respect for Poland from abroad was 
put forward primarily in order to build the ruling elite's public image at home. The introduction of historical and symbolic issues to foreign policy served chiefly to consolidate the party electorate and eliminaterivals in internal politics (Miller 2012: pp. 9-32).

The phenomenon, which is characterized in this text under the name of the hypertrophy of remembrance policy or politics of memory, is now found throughout Central and Eastern Europe. It has three unique features. First, it gives strategic importance to goals for which it would be necessary to pay such high a price that it would render it unacceptable for democratic public opinion (if it were aware of it). If one party considers that "dignity" cannot be negotiated, then the counterpart will arrive at the same conclusion. Ultimately, the partner's concession can only be obtained by a war or an offer of enormous benefit. At the same time, one can keep on convincing one's own society that only the ill will of the other party stands in the way of achieving the goal of consensus. This provides a steady source of votes from dissatisfied people.

Second, it allows to devote more and more budgetary resources to historical and symbolic activities, to which the public becomes gradually accustomed. Admittedly, this endorsement comes to an end when there are a fewyears of a decline in GDP, which happened to most countries in the discussed region in 2008-2009. However, Poland remained a "green island" of GDP increase and consequently investments in the infrastructure of remembrance policy continued to flow in the period.

Third, it distracts public attention from current problems and directs it to the past, the time supposedly characterized by a greater national fervor than the present. This creates an illusion of the existence of a bond in the present, chiefly in order to stop the growing individualization, forced on a nation by civilization changes. But actions aimed at strengthening "dignity" through national identity are not the right means to shape civic attitudes or to develop social sensitivity. 
Among the countries of Central and Eastern Europe, Poland is experiencing the hypertrophy of the politics of memory at the largest scale. It is a pioneer in institutional solutions developed to this end and allocates the largest budgetary resources to it. In Poland, the authorities promote univocal interpretations of events from 1939-1989, on the premise of the erroneous assumption that strengthening national pride is a condition sine qua non for modernizing the economy, increasing wealth and reducing social differences. The current agenda of Law and J ustice is for Poland to take over the role of a moral and political leader of the entire region of post-communist countries, thus ensuring that the country has a place in Europe equal to that of Germany or France. The remembrance policy of the Polish right-wing, pushing into "oblivion" what is controversial, gives rise to antagonism rather than consolidation. I shall present here how it plays out on both the internal and international dimensions.

Hypertrophy of remembrance policy

As far as the infrastructural dimension is considered, the hypertrophy of this element of remembrance policy in Poland is expressed by the calendar saturated with national holidays and days commemorating the martyrdom and heroic symbols from the period of 1918-1989, but especially 1939-1956. Although the right-wing governments that have ruled since 2015 do not stand out from their predecessors in this respect, it should be noted that there has been a certain reinforcing of the trend under their rule. Earlier in the official calendar there used to be ten national holidays and days commemorating martyrdom and heroism (including Katyń, Nazi extermination camps, the Warsaw Uprising, the martial law) and two international days (Holocaust, 27 J anuary; Victims of Stalinism and Nazism, 23 August). In the period from 2015 on- 
wards, new symbolism was affixed to the National Day of the Remembrance of the "Cursed Soldiers" on 1 March. The current authorities focused on honouring the commanders who, in 1944 and later, acted without formal orders or within the national camp, representing the attitude of non-acceptance of any post-war changes and armed combat usque ad finem. They chose to turn a blind eye to such "nuances" in the biography of Colonel Zygmunt Szendzielarz "Lupaszko" as the raid carried out by his $5^{\text {th }}$ Vilnius Home Army Brigade in J une 1944, during which dozens of civilians in Dubinki and several other Lithuanian villages were murdered. It was interpreted as a "response" of the Polish underground to the earlier crimes of the Lithuanian police perpetrated on the Poles (Rokicki 2015).

The promotion of this otherwise distinguished officer as the main symbol of the Cursed Soldiers contributed to lifting the anathema from other commanders too. But in many other cases, independence activity can no longer be easily separated from nationality crimes or ordinary banditry. As a consequence, there is ongoing heroization of acts committed by such individuals as Józef Kuraś "Fire" in Podhale, Romuald Rajs "Drab” in Podlasie and J ózef Zadzierski "Volhynian” in Rzeszów. The instances of murder by their troops in the years 1945-1946 civilian J ews, Slovaks, Belarusians and Ukrainians are beingjustified by the fact that the victims served the communist state or that these were acts of retaliation for crimes against the Poles (Podwójnie wyklęty 2017).

In all fairness, it must be admitted that the idea of commemorating post-war armed resistance is not new. Bronisław Komorowski, as the Minister of Defence in the 1990s, and as President in 2010-2015, has also contributed to this heroization. For instance, in 2011 he established the National Day of the Cursed Soldiers. Nevertheless, considering the whole of his remembrance policy, it can be concluded that it was directed at civil resistance of organizations such as the Association "Freedom and Independence" than being about the then already futile armed 
struggle, more so that its victims were often people who were not associated with the occupier or the communist authorities.

To the previous practices of celebrating acts of martyrdom and heroism, the Sejm of the 8th term added two more positions, notably 11 J uly National Day of Remembrance of Genocide Victims perpetrated by Ukrainian nationalists on citizens of the Second Polish Republic, to which I return later in the text. Ultimately, there are only three months (February, October and November) without any such celebrations and this saturation seems to aim at cementing the relationship between society and acts of national heroism and martyrdom, However, the time entirely free from the memory of suffering and struggle is in fact limited to February only, because there are two more days of not so unambiguous but still similar connotation: The Day of Pope J ohn Paul II on 16 October and National Independence Day on 11 November.

Identity policy of the Institute of National Remembrance

Although similar institutions have also been established in other countries of the region, the Institute of National Remembrance (IPN), set up first, remains unsurpassed. Only the Polish organization has a branch structure, comprising eleven regional branches and seven delegations, in total more than the number of voivodeships. According to the intentions of the legislators of 1998, the Institute was divided into three departments charged with three distinct duties: 1) conducting scientific research and the dissemination of its findings, 2) storing and providing access to archives of security services and 3) prosecuting Nazi and communist crimes (Law 1998; Koczwańska-Kalita 2015; Dudek 2011).

According to these objectives, the Institute of National Remembrance had the chance to become a unique institution of transitional justice, based on the principles of human rights protection. Let us recall that the goal of this form of justice is the restoration of the rule of law, 
political community and trust in the state in countries that have gone through dictatorship and/ or war. The means of this justice are above all: reparation to victims, punishment of perpetrators, creation of new narratives about the past and education about the past in order to prevent threats to democracy (Transitional Justice in Eastern Europe and the Former Soviet Union. Reckoning with the Communist Past 2009).

The shortcoming and failure of the Institute of National Remembrance turned out to be the statutory dependence of its leadership on the balance of power in the Sejm. Resultantly, the change of the ruling party and the swearing in of a new Sejm meant changes in the structure of the Institute's council and the function of its president. As early as in 2005-2010, the Institute of National Remembrance was transformed into an institution mainly involved in shaping the national identity, although this process was mitigated by the authorities during their subsequent term in office (2011-2016).

Transitional justice has, by its nature, a temporary character. According to this logic, the Institute's activity should have first remained at the initial level or have slightly increased along with the recognition of the scale of needs, but then it should have started to gradually diminish. However, in almost twenty years of its operation, the Institute's budget has increased by slightly more than $100 \%$. While in the first two years of operation, in the years 2001-2002, it amounted to about 180 million PLN, in 2015 it was already 249 million, in 2017, 289 million, and in 2018 the figure was as high as 363 million.

After the last change of management in mid-2016, the Institute of National Remembrance became again an institution of identity policy. An expression of this policy is not only the conduct of activities that the authorities perceive as a fight against the defamation of Poland in the international arena, but also the implementation of a broad plan of exhumation of "cursed soldiers" and other victims from the period 1944- 
1953 on the territory of Poland. This is accompanied by an intense educational campaign. At the same time, for many years, the number of cases of crimes of 1939-1953 concluded with the accusation reaching the court amounts to only a dozen or so annually (with the Institute employing over one hundred prosecutors).

The Act of 29 April 2016 abolished the participation of the scientific community of historians in the appointment of the President of the Institute of National Remembrance, giving politicians an unrestrained control over this process. The scope of the Institute's responsibility was extended to include the period when the Bolsheviks assumed power in Russia, whereas previously it covered only the period of 1939-1990. The existing structure of the Institute was enlarged, reflecting its four main tasks (in accordance with the amendment from 2006, the Lustration Office was added to three original offices). The Office for Commemorating Combat and Martyrdom and the Office for Search and Identification were also created. The research and education division was divided into two: Historical Research Bureau and National Education Office. In the end, seven divisions were created. During past tenures, the Institute conducted research not only on repression and resistance, but also on social issues in the period 1944-1989. It was not shying away from publishing works on issues controversial for the public (Moroz 2016; J arska 2015).

As such, the Institute did not stand out from the tendencies in contemporary world historiography. What is more, previous management was ready to get feedback from representatives of the Polish humanist professorship and learn how experts evaluate their activities, organizing conferences on its image and duties every few years (Pamięć $i$ polityka historyczna. Doświadczenia Polski i jej sąsiadów 2008; Bez taryfy ulgowej. Dorobek naukowy i edukacyjny Instytutu Pamięci Narodowej 20oo-2010 2012). Under the new management, these directions of re- 
search and action were abandoned. Concentrating almost all the functions of the state's remembrance policy in Poland, the National Remembrance Institute, together with the Ministry of Culture and National Heritage (MKiDN), approached the ideal of the Orwellian "Ministry of Memory".

Museum infrastructure

Regarding the museum infrastructure in the context of the politics of memory, previously commenced projects, going back to 2015, are being continued, while new ones are being launched. Some have been going on for more than a decade and are yet to be completed, including the Museum of Polish History, established in 2006. The construction of its headquarters at the Citadel has been underway since 2018, as has been the construction of its neighbour, the new headquarters of the Polish Army Museum.

Another project, The J ozef Pilsudski Museum in Sulejowek, received state funding in 2008, but as of November 2018 the facility had not yet been completed. Additionally, in recent years, local governments, among others with the support of European funds, have built, or are in the process of constructing, museums with national ambitions. Thus, in 2015, Gdynia saw the opening of the Museum of Emigration, and Katowice, a new exhibition of the Silesian Museum. In turn, in 2010, the Oskar Schindler's Enamel Factory in Krakow housed an exhibition on the subject of Nazi occupation, while in Bialystok, the Siberia Memorial Museum is being organized. In Gdansk, between 2007and 2014, a large investment from the local government helped to erect The European Solidarity Centre. Only the Museum of the Polish People's Republic in Krakow Nowa Huta, founded in 2008 , did not receive any government subsidy. 
There are also initiatives going back to the 1990s, such as the Katyn Museum in Warsaw or the Home Army Museum in Krakow. Strong arguments for the implementation of each of the projects have been put forth. In other cases, in the last decade, museums commemorating extermination camps in Poland had their exhibitions overhauled (Auschwitz, Majdanek) or were built entirely new (Malkinia, Sobibor, Belzec). However, one could pose the following questions: will not the large scale of the commemoration of the martyrologic and heroic narratives prove counterproductive? Will not such a strong emphasis on the remembrance policy lead to the conviction of both Poles and foreign visitors that Polish identification with the community is nothing but the cultivation of "apocalyptic" experience of the 20th century? Will not the effect of this policy, inter alia, be the rejection of this interpretation of history (and along with it, the rejection of Polishness) by coming generations?

The Polish authorities have not added much to the museum infrastructure since the end of 2015. However, it is significant that their prime aim in this domain has been to commemorate the influence of the Polish "civilization" in the East as well as to fight the perceived threats coming from that "direction". And so, in 2017, the government agreed to the Lublin authorities' request to finance the purchase of the seat of the future Museum of Eastern Territories of the First and Second Polish Republic (originally under the name of the Museum of the Eastern Borderlands). They also support two initiatives: the first to be devoted to the Cursed Soldiers and the Political Prisoners of The Polish People's Republic (it is being created in the former prison of the Ministry of Public Security in Warsaw), and one that will concern only postwar armed resistance (it is being built, with the support of the government, by the authorities of Ostroleka). In August 2017, the Ministry of National Defence also announced the creation of a large Museum of the 
Battle of Warsaw and the Cultural Park called the Battle of Warsaw Battlefield in Ossow near Warsaw.

Given the existence of a robust research division of the Institute of National Remembrance and research departments in many of the listed museums, as well as numerous historical institutes at universities and the Polish Academy of Sciences, it should be questioned whether it was necessary to create additional institutions aimed at documenting and commemorating the martyrdom and heroism of Poles. In May 2016, the Centre for Research on Totalitarianisms named after Witold Pilecki was established. According to its mission, a greater emphasis will be placed on German and Soviet crimes, as well as on providing sources reports referring to them to foreign researchers. Most probably, the authorities wish to create a ripe ground for competent criticism of the view popular in Western Europe that Stalinism and communism on the whole had different structural features (and not as drastic consequences) from the regimes of Hitler and Mussolini, and that consequently the category of totalitarianism in science is unnecessary (Žižek 2005).

Polemic with this view is indeed long overdue. However, the establishment of the Centre should be seen primarily in connection with the authorities' anti-defamation policy. It is supposed to implement it through positive actions, that is the promotion of Polish history, not negative ones, such as punishing people for passing on facts or conscious defamation. This task is even more expressly assigned to The Institute of Solidarity and Bravery set up in November 2017. It acts as a research institute and honours people in Poland and abroad for "the work of nurturing the memory of or providing help to people of Polish nationality or Polish citizens of other nationalities who were victims of mass atrocity crimes" (Law 2017) in the years of 1917-1989. When questioned why the IPN should not be carrying out the research tasks of these two institutions, the authorities responded that the Institute would be overburdened if it were do so. The Centre and the Institute of 
Solidarity and Bravery are intended for foreign interest; they train their employees in the field of foreign languages and grant scholarships for the use of Polish sources for foreign researchers, obliging them to publish their works in English (Gawin: Instytut Solidarności i Męstwa wprowadzi polskie źródła do światowej historiografii 2018). This argument is difficult to call into question, especially if we refer to the low level of internationalization of research activities of the Institute of National Remembrance. However, it results from the fact that the state continues to pursue a policy of expanding the infrastructure of the Polish remembrance policy, instead of reducing those structures that have not worked or have exhausted their mission.

Antagonizing outcomes, both nationally and internationally

A more serious problem than the increase in expenditures on remembrance policy is creating or aggravating the divisions resulting from the reinterpretation and revision of Polish history as well as that of foreign countries. There are six issues here. First, it is an attempt to discredit Lech Walesa by casting doubt on the credibility of his life path. At stake in this fight is not the final determination of what his contacts with the Security Service in the first half of the 1970s were, but his removal from the group of people deemed to have an honourable place in the history of Poland and the negative assessment of the emergence and first years of the rule of the Third Polish Republic.

Most of all, this policy antagonizes Polish public opinion, although it also has an effect of bewildering people abroad. Walesa entered the narrow circle of people whom the international public infallibly associate with the history of Poland. Trying to deprive him of this place for the benefit of figures of secondary consequences for the development of the situation in Poland in 1980-1995, notwithstanding their significance for development of independent trade unions in Gdańsk, Law and J ustice 
undermines not only the position of the current opposition, who support Lech Wałęsa, but also the authority of foreign institutions that have recognized Lech Wałęsa's past achievements. After all, the former president is one of less than a handful of Nobel Peace Prize laureates (1983) representing the countries of Central and Eastern Europe (in addition to Andrei Sakharov and Mikhail Gorbachev), and the only foreign politician who, in recognition of his historical merits, was invited to address the US Congress without holding any state function (1989).

Second, it is difficult to avoid the impression that the motives for the Decommunization Act of 1 April 2016 (Law 2016a) were primarily to preserve Poland's superiority in competition to prove which of the Central and Eastern European nations contributed the most to the fight against totalitarianism. Most probably, the matter would not have gained such a great significance in this parliamentary term, were it not for the Russo-Ukrainian war and the adoption of the decommunization law by the Verkhovna Rada of Ukraine on 9 April 2015. However, in Ukraine, the removal of thousands of Soviet topographic names and hundreds of Lenin monuments in the context of the ongoing war must be seen in the context of nation-building.

On the other hand, in Poland, similar actions are more reminiscent of "driving a wooden stake" into the vampire of Russia's politics of memory (whose main focus is the Great Patriotic War), which the Polish authorities have no influence on. By amendment of this law of $22 \mathrm{~J}$ une 2017, the parliament also ordered the clearance of monuments "promoting the totalitarian regime", including monuments of gratitude to the Soviet army (Law 2017b; Czarnecka 2015). The Act put an end to the discussion on the assessment of those historical Polish characters who, like for example, General Zygmunt Berling or volunteers from the Brigade named after Jaroslaw Dąbrowski in the Spanish Civil War, 
made decisions too ambiguous to be summed up by only a few sentences of the IPN ruling concluding that they served to build a "totalitarian" Stalinist system.

On the other hand, the act of Parliament of 16 December 2016 limiting pensions of people who were employees of the security sector in the years 1944-1990. It is faulted for accepting that by serving the "totalitarian state" those people did not work at all, for equating the responsibility of the investigating officer, IT specialist and secretary, and for rejecting the state's obligations towards officers positively verified in 1990 (Law 2016c).

Third, the policy of prioritizing the memory of antagonistic historical consequences reared its ugly head by depriving the creators of the Museum of the Second World War in Gdansk their management roles, as they were not willing to "nationalize" the museum's narrative. They were dismissed, and the new management strives now to limit the international context of contemporary events in Poland, shifting attention from the fate of "ordinary" people, representative of individual communities, to heroic characters, and erasing the final pacifist message from the exhibition. The closing film, showing the conflicts of the Cold War in a negative light and the contemporary use of force by the powers to solve international problems, was replaced by a picture aimed at demonstrating the uniqueness of Polish contribution in 1939-1945 and ennobling the armed struggle as a morally right way to achieve one's goals.

In this way, the Museum "returned" to the didactic function, which state institutions performed until the beginning of the process of reconciliation between European nations after World War II. I refer here to attempts to secure the readiness of a citizen to make the ultimate sacrifice of their lives as a norm of civic duty in place of teaching one how to avoid repeating disastrous actions that were unavoidable in the past. Forcing the change of museum management led to a deep division 
within the contemporary research community in Poland and the weakening of the position of Polish historiography on the international arena.

Fourth, it must be noted that the actions of theauthorities in thearea of Polish-Ukrainian relations have led to decidedly negative consequences. On 22 J uly 2016, the Sejm qualified the anti-Polish action of OUN-UPA (The Organization of Ukrainian Nationalists/The Ukrainian Insurgent Army) in Volhynia and Eastern Galicia as genocide. It adopted the said resolution on 11J uly, the anniversary of the murder of the villagers from Poryck/ Pawliwka and dozens of other settlements on that day in 1943, and it gave the day the official status of a remembrance day (Resolution 2016). Next in his speeches, the president of Law and J ustice, J arosław Kaczynski, made good relations between Poland and Ukraine directly dependent on Ukraine's acceptance of the genocidal qualification of these crimes.

Later, the police and the prosecutor's office proved extremely "inept" in prosecuting the perpetrators of the destruction of Ukrainian commemorative sites in Poland devoted to the nation's military effort and victims from 1943-1947 and proved equally unable to bring action against acts of hate speech against Ukrainian citizens. Finally, the Ministry of Internal Affairs and Administration, responsible for subsidies for national minority organizations, for the first time since 1990 ignored the celebrations of the seventieth anniversary of Operation "Vistula" (forced resettlement of the Ukrainian minority) that is the very foundation of the collective memory of the Ukrainian minority. Extreme methods employed by Law and J ustice, whose goal was to get the authorities in Kiev to condemn UPA actions, backfired. The path chosen by the Polish side was perceived in Ukraine as humiliating and was flatly rejected. On the one hand, the choice of these methods was based on the overestimation of the strengths in Poland's eastern policy. On the other 
hand, the Ukrainian elites remain now well aware that the Polish authorities have been falling into isolation in the EU since 2015, among others precisely because of too much attention they have been giving to remembrance policy in general.

Fifth, the excessive significance ascribed to national dignity has pushed the ruling party into conflict with its allies: Israel and the United States. It jeopardized all the achievements of the work that went into the promotion of the image of Poland of World War II, the effort that can be traced to at least to the 2001 state commemoration of the victims of the J edwabne pogrom of Polish J ews. Putting in danger these accomplishments, in the amendment to the Act on the Institute of National Remembrance of 26 J anuary 2018, the Sejm imposed a penalty up to three years in prison for statements attributing responsibility "for the Nazi crimes committed by the Third Reich to the Polish Nation or the Polish State" (Law 2018).

Such an attempt by the Polish authorities to counteract the occurrence of the phrase "Polish death camps (extermination camps, concentration camps)" in the media abroad was received as an expression of a lack of faith on the part of the Polish authorities in the effectiveness of positive measures, which, among others, should include providing information on the responsibility of the Third Reich for the Holocaust in the Polish lands. Paradoxically, institutions whose goal was to use precisely such measures were created already before 2015, as well as after this date. From the very beginning, following the amendment, it was obvious that no one would comply with the new provisions outside of Poland, which meant that legislators were laying down an unfeasible law.

There was the impression that the authorities want to hide such cases as the pogrom on $10 \mathrm{~J}$ uly $1941 \mathrm{in} \mathrm{J}$ edwabne and limit the freedom of research of domestic and foreign historians. Admittedly, such researchers would be protected by a provision that excludes penalties for 
statements made "as part of artistic or scientific activity", but could anything prevent the court from imposing a custodial sentence on, say, J an Tomasz Gross, the author of critical books on the attitude of Poles to the Holocaust (Gross 2001; Dalej jest noc. Losy Żydów w wybranych powiatach okupowanej Polski 2018), if it interprets one of the writer's statements as "journalistic"? Such threats also concern researchers who use the term "concentration camp" in relation to crimes committed by Polish state officials, consistingin creating conditions resulting in death from illness, starvation and exhaustion of political prisoners. It applies to camps in: Bereza Kartuska (1934-1939), officially a "place of detention", Świętochłowice-Zgoda (in 1945, detaining mainly Germans and Silesians) and Jaworzno (1945-1949, from 1947 used for Ukrainians and Lemkos deported under the "Vistula" action), called "labour camps" (Łuszczyna 2017).

The amendment to the Act on the IPN was met with unequivocal criticism from Israel and the United States. Already in J une 2018 the risk resulting from the possible withdrawal of the United States from their additional obligations to defend Poland given to the Polish authorities after the outbreak of the Russo-Ukrainian war, prompted the Polish state to reach a settlement with Israel and add another amendment to the law, cancelling thus the provisions restricting the freedom of research and expression on the Holocaust. Ukraine however was treated differently. Prime Minister Mateusz Morawiecki, on 13 February 2018, suggested that the wave of anti-J ewish pogroms during the uprising of Bohdan Chmielnicki in Ukrainian lands in The First Rzeczpospolita in XVIIth century was an event preceding the Holocaust (Trojan 2018).

Doing so, the authorities wanted to convince Israel and international public opinion that Poland best in Central and Eastern Europe cares about the truth about the Holocaust. However, they did it, among others, at the expense of the reputation of the eastern neighbour. It is true that the Ukrainian leadership, since the independence of the country in 
1991, has not reviewed the OUN's (The Organization of Ukrainian Nationalists) anti-Semitic propaganda and the anti-J ewish pogroms of 1941 in the western part of the country, but this kind of "concern" of the Sejm for J ewish citizens of the Second Polish Republic could not have been seen as genuine or credible.

After all, almost simultaneously the Polish authorities attempted to penalize the statements regarding the participation of Poles in the Holocaust. The Ukrainian Institute of National Remembrance used the crisis around Poland and announced that it would not allow the Ukrainian participants of the Common Historians' Forum in Poland to visit it again, and that any further work of this body should now be held only in Ukraine (Zaiava 2018). That meant the deepest crisis of the dialogue between Polish and Ukrainian researchers, a dialogue that had been conducted without interruption since 1991. It was received equally bad in Ukraine that when the Polish authorities finally decided to withdraw the provisions of the law on the Holocaust, none of the lawmakers in the Sejm said anything whatsoever to acknowledge the need to change the entries referring to the Ukrainian nationalist movement.

Finally, on the positive note, some steps have been taken to solve the issue of the Smolensk crash, which has been dividing Polish society the most. In the summer of 2017, the Law and J ustice chairman announced that the 96th monthly commemoration of the catastrophe, known as mensiversary in Poland, on 10 April 2018 will be the last one, as 96 was the number of the victims of the crash. Subsequently, the voivode of Mazovia, under the procedure of Decommunization Act, gave the fragment of Lazienkowska Thoroughfare in Warsaw the name of Lech Kaczyński.

In 2018, two monuments were unveiled: a collective one of all the victims of the crash and a separate one, of the president himself, both in a highly representative location on Pilsudski Square near the Tomb of the Unknown Soldier. These steps promised to limit the tension 
around this issue. However, the intentions of the authorities were not entirely clear. They did not withdraw completely from attempts to prove that the crash was the result of a Russian coup. The main proponent of this thesis, former minister Antoni Macierewicz, was allowed to continue his "research" work, although the rank of his team was downgraded. Thus, Law and J ustice leadership did not choose to definitively abandon one of its main tools of the mobilization of dissatisfied voters. Probably, this owes a lot to the fact that the trauma of J arosław Kaczyński and his entourage brought about by the tragedy legitimizes in the eyes of the public the romantic-traditionalist notion of Polishness, which in turn underlies the ruling party's martyrologic-heroic remembrance policy.

\section{Summary}

The Polish authorities are striving to reorganize the EU towards a confederal 'Europe of nations'. They perceive US Republicans and British Conservatives of the Brexit era as their allies in achieving this goal. On the one hand, not only in Poland, but also in other countries of Central and Eastern Europe, anti-globalization tendencies have been taking the form of a "return" to the twentieth-century nation state. On the other hand, the public opinion of the "old" European countries is losing sympathy for the "new" members and within a few years may become disinterested in whether those countries will participate in the next stage of integration.

The "scenario" seen as pessimistic from the point of view of security and cooperation in Europe can be contrasted with the position of a country "cleansing" itself of the sources of martyrdom and heroic policy of remembrance and identity. As far as Poland is concerned, one may assume that, after the celebration of the 100th anniversary of independ- 
encein 2018-2021, the saturation of the memory infrastructure protecting national identity in the form of holidays, museums, promotional institutions and legal acts will have encompassed all the emotional problems of modern history. Secondly, the failure of Law and Justice in achieving any of the aims of its politics of memory during the period of its rule will encourage the next government to remove them from the foreign policy agenda. Thus, actions aimed at cultivating remembrance will "drop" from the state level to the level of self-governments and institutions of civil society. Municipalities and NGOs will continue to take care of places of remembrance and cultural artefacts, but above all, more with the purpose of making money on tourists or winning competitions like the European Capital of Culture. Thirdly, in the not so distant future, a generation of Central and Eastern Europeans who either personally remember World War II or were shaped in the atmosphere of unhealed post-war wounds, Stalinist repressions or the most severe phase of the Cold War confrontation will have passed away.

However, there are also some unknowns casting doubt on to whether this optimistic "scenario" will come true. It is not known in how the media will develop and how it will be used. Will it be possible to stop the process of people closing themselves in "online bubbles" or halt the flood of hate speech without limiting basic freedoms? Will the popularity of "gothic" computer games pass, a pastime that makes youngsters identify themselves with historical heroes who clash against the "entire world"? Will civil society in Russia get out of the current impasse and change the country's provocative policy of memory, which the authorities direct against its western neighbours?

Regardless of what future will bring, it is worth imagining now about such a Polish remembrance policy that would symbolize and engender openness to other communities. This could be done through, for instance, commemorating arguably the most important among unknown events of the $20^{\text {th }}$ century, namely the death from starvation in 1941- 
1945 of at least half a million prisoners of the Red Army in German camps in Poland (Jeńcy sowieccy na ziemiach polskich $w$ czasie II wojny światowej 2015). If this were done before fundamental changes in Russia take place, it would be a constructive act of changing the criteria of the Polish remembrance policy - from particular to universal.

\section{References}

Czarnecka D. (2015), „Pomniki wdzięczności” Armii Czerwonej w Polsce Ludowej i $w$ III Rzeczypospolitej [The Red Army "gratitude monuments" in Polish People `s Republic and the Third Polish Republic], IPN - KŚZpNP, Warszawa

Dalej jest noc. Losy Żydów w wybranych powiatach okupowanej Polski (2018), [Continue is night. The Fate of the Jews in the chosen counties of the occupied Poland], (Eds.) Engelking B., Grabowski J., Vol. 1, 2, Centrum Badań nad Zagładą Żydów, Warszawa

Dudek A. (2011), Instytut. Osobista historia IPN [The Institute. Personal history of the Institute of National Remembrance], Czerwone i Czarne, Warszawa

Gawin: Instytut Solidarności i Męstwa wprowadzi polskie źródła do światowej historiografii [Gawin: The Solidarity and Bravery Institute will introduce Polish sources to world historiography] (2018), GazetaPrawna.pl, https:/ / kultura.gazetaprawna.pl/artykuly/ 1104350,minister-gawin-o-instytut-solidarnosci-i-mestwa.html

Gross J.T. (2001), Neighbors: The Destruction of the Jewish Community in Jedwabne, Poland, Princeton University Press, Princeton

J arska N. (2015), Kobiety z marmuru. Robotnice $w$ Polsce w latach 1945-196o, [Women of marble. Women workers in Poland 1945-1960], IPN KŚZpNP, Warszawa 
Jeńcy sowieccy na ziemiach polskich w czasie II wojny światowej (2015), [The Soviet prisoners of war during the II World War], (Ed.) Wojtkowiak J., Centrum Polsko-Rosyjskiego Dialogu i Porozumienia, Warszawa Koczwańska-Kalita D. (2015), (Nie)chciane dziecko III RP. Instytut Pamięci Narodowej 200o-2010. Geneza, funkcjonowanie, kontekst spoleczny i polityczny [(Un)wanted child of the Third Rzeczpospolita. The Institute of National Remembrance: origin, functioning, social and political context], Arcana, Kraków

Law (1998), Ustawa z dnia 18 grudnia 1998 r. o Instytucie Pamięci Narodowej - Komisji Ścigania Zbrodni przeciwko Narodowi Polskiemu (1998), Dz.U. z 1998 r. Nr 155, poz. 1016

Law (2016a), Ustawa z 1 kwietnia 2016 r. o zakazie propagowania komunizmu lub innego ustroju totalitarnego przez nazwy budowli, obiektówi urządzeń użyteczności publicznej [Law from 1 April 2016 on the prohibition of propagation of communism or other totalitarian regime by names of buildings, facilities and public utilities], Dz.U. 2016 poz. 744, http:// prawo.sejm.gov. pl/isap.nsf/ download.xsp/ WDU20160000744/U/D20160744Lj.pdf

Law (2016b), Uchwała Sejmu RP z 22 lipca 2016 r. w sprawie oddania hołdu ofiarom ludobójstwa dokonanego przez nacjonalistów ukraińskich na obywatelach II Rzeczypospolitej Polskiej w latach 1943-1945 [Seim Resolution from 22 July 2016 on the homage to the victims of genocide committed by Ukrainian nationalists on citizens of the Second Rzeczpospolita in 19431945], M.P. 2016 poz. 726, http:/ / dziennikustaw.gov.pl/mp/ 2016/ 726/ 1

Law (2016c), Ustawa z 16 grudnia 2016 r. o zmianie ustawy o zaopatrzeniu emerytalnym funkcjonariuszy [Law from 16 December 2016 on amending the law on retirement provision for officers], Dz.U. 2016 poz. 2270, http:// www.dziennikustaw.gov.pl/ du/2016/2270/1

Law (2017a), Ustawa z 9 listopada 2017 r. o Instytucie Solidarności i Męstwa im. W. Pileckiego [Law from 9 November 2017 on the Witold Pilecki Institute of Solidarity and Valor], Dz.U. 2017 poz. 2303 
Law (2017b), Ustawa z 22 czerwca 2017 r. o zmianie ustawy o zakazie propagowania komunizmu lub innego ustroju totalitarnego przez nazwy budowli, obiektów i urządzeń użyteczności publicznej [Law from 22 J une 2017 on amending thelaw on the prohibition of propagation of communism or other totalitarian regime by names of buildings, facilities and public utilities], Dz.U. 2017 poz. 1389, http:// prawo.sejm.gov.pl/isap.nsf/ download.xsp/ W DU20170001389/O/D20171389.pdf

Law (2018), Ustawa z dnia 26 stycznia 2018 r. o zmianie ustawy o Instytucie Pamięci Narodowej - Komisji Ścigania Zbrodni przeciwko Narodowi Polskiemu, ustawy o grobach i cmentarzach wojennych, ustawy o muzeach oraz ustawy o odpowiedzialności podmiotów zbiorowych za czyny zabronione pod groźbą kary [Law from 16 J anuary 2018 on amending the law on the Institute of National Remembrance], Dz.U. 2018 poz. 369, http:/ / www.dziennikustaw.gov.pl/ du/2018/369

Łuszczyna M. (2017), Mała zbrodnia. Polskie obozy koncentracyjne [The Small Crime. Polish concentration camps], Znak Horyzont, Kraków

Miller A.(2012), Istoricheskaia politika $v$ Vostochnoy Yevrope $v 21$ veke [The politics of memory in the Eastern Europe in the XXI century], (in:) Istoricheskaia politika $v 21$ veke [The politics of memory in the XXI century], (Eds.) Miller A., Lipman M., Novoie Literaturnoie Obozreniye, Moskwa

Moroz A. (2016), Między historiq a pamięcia, Konflikt pamięci zbiorowych Polaków i Białorusinów na przykladzie postaci Romulada Rajsa „Burego”[Between history and memory. The Polish-Belarusian conflict of collective memories on the example of Romuald Rajs "Drab"], IPN - KŚZpNP, Warszawa Podwójnie wyklęty (2017) [Double damned], director E. Szakalicka (movie) Rokicki P. (2015), Glinciszki i Dubinki. Zbrodnie wojenne na Wileńszczyźnie $w$ połowie 1944 roku $i$ ich konsekwencje we wspótczesnych relacjach polsko-litewskich [Glinciszki i Dubinki. The war crimes in the Vilnius Region in the middle of 1944 and their consequences in the contemporary PolishLithuanian relations], IPN - KŚZpNP, ISP PAN, Warszawa 
Transitional Justice in Eastern Europe and the Former Soviet Union. Reckoning with the Communist Past (2009), (Ed.) Stan L., Routledge, NewYork Trojan M. (2018), Morawiecki zacytowat rabina [Morawiecki quoted rabbi], Kresy.pl, https://kresy.pl/wydarzenia/morawiecki-zacytowal-rabina-chm ielnicki-zbrodniarz-hitler-himmler-ukraincy-oburzeni-video/

Zaiava (2018), Statement of the Ukrainian Institute of National Remembrance, http:// www.memory.gov.ua/ news/ zayava-ukrainskogo-institutunatsionalnoi-pam-yati-shchodo-nemozhlivosti-prodovzhennya-roboti-u Žižek S. (2005), The Two Totalitarianism, “London Review of Books” Vol. 27, No. 6 